\title{
Lab-on-a-Membrane Foldable Devices for Duplex Drop-Volume Electrochemical Biosensing Using Quantum Dot Tags
}

Christos Kokkinos $^{* \dagger}$, Michailia Angelopoulou ${ }^{\S}$, Anastasios Economou ${ }^{* \dagger}$, Mamas Prodromidis ${ }^{\ddagger}$, Ageliki Florou ${ }^{\ddagger}$, Willem Haasnoot ${ }^{\perp}$, Panagiota Petrou ${ }^{\S}$, Sotirios Kakabakos ${ }^{\S}$

${ }^{\dagger}$ Laboratory of Analytical Chemistry, Department of Chemistry, University of Athens, Athens, 157 71, Greece.

$\ddagger$ Laboratory of Analytical Chemistry, Department of Chemistry, University of Ioannina, Ioannina, 45110, Greece.

${ }^{\S}$ Immunoassays/Immunosensors Lab, INRaSTES, NCSR “Demokritos”, Aghia Paraskevi, 15310, Greece.

${ }^{\perp}$ RIKILT Wageningen UR, Akkermaalsbos 2, WB Wageningen, 6708, The Netherlands.

*E-mail addresses: xkokkinos@gmail.com; christok@chem.uoa.gr (C. Kokkinos), aeconomo@chem.uoa.gr. (A. Economou) 


\section{Comparison of chromatographic paper and nylon membrane as substrates for the}

development of electrochemical immonoassays.

In order to compare chromatographic paper (Whatman \#1 Chr) and nylon membrane (Biodyne B) as substrates for the development of electrochemical immunoassays, a model binding assay involving biotinylated BSA and streptavidin (STV)-modified CdSe/ZnS QDs is employed. For this purpose, $5 \mu \mathrm{L}$ of $100 \mu \mathrm{g} \mathrm{mL}^{-1}$ biotinylated BSA in $20 \mathrm{mmol} \mathrm{L}^{-1} \mathrm{PBS}, \mathrm{pH}$ 7.0 , is transferred on a circular assay zone on a nylon membrane $(0.8 \mathrm{~cm}$ diameter $)$ and on a circular piece circular assay zone on chromatographic paper (Whatman \#1 Chr) with the same diameter and left to immobilize for $15 \mathrm{~min} .20 \mu \mathrm{L}$ of $2.5 \%(\mathrm{w} / \mathrm{v})$ BSA solution in PBS containing also $0.05 \%(\mathrm{v} / \mathrm{v})$ Tween 20 is placed on each assay zone and left for $30 \mathrm{~min} .15 \mu \mathrm{L}$ of STV-conjugated CdSe/ZnS QDs solution (5 nmol L ${ }^{-1}$ in $20 \mathrm{mmol} \mathrm{L}^{-1} \mathrm{PBS}, \mathrm{pH}$ 7) is added to each substrate and left to react for $20 \mathrm{~min}$. The two substrates are washed four times with $50 \mu \mathrm{L}$ of $0.1 \%$ Tween solution in distilled water and dried. $10 \mu \mathrm{L}$ of $0.01 \mathrm{~mol} \mathrm{~L}^{-1} \mathrm{HCl}$ solution is placed on each circular assay zone for $10 \mathrm{~min}$ to release $\mathrm{Cd}(\mathrm{II})$ from the QDs labels. Each circular assay zone was placed on the surface of a three-electrode screen-printed electrochemical cell. The cell was printed on a $0.175 \mathrm{~mm}$ thick polyester sheet (CUS7, Mac Dermid) and featured a working a graphite working electrode loaded with bismuth citrate $(6 \% \mathrm{w} / \mathrm{w})$, a graphite counter electrode, a silver pseudo-reference electrode and an overlay dielectric layer. $15 \mu \mathrm{L}$ of acetate buffer $\left(0.1 \mathrm{~mol} \mathrm{~L}^{-1}, \mathrm{pH} 4.5\right)$ is placed on each substrate and the released $\mathrm{Cd}(\mathrm{II})$ is detected by SWASV with preconcentration at $-1.40 \mathrm{~V}$ for 240 s. Similar results are obtained when STV-conjugated PbS QDs are used as labels (solution containing $4.3 \mathrm{nmol} \mathrm{L}{ }^{-1} \mathrm{PbS}$ QDs in $20 \mathrm{mmol} \mathrm{L}^{-1} \mathrm{PBS}, \mathrm{pH}$ 7). 


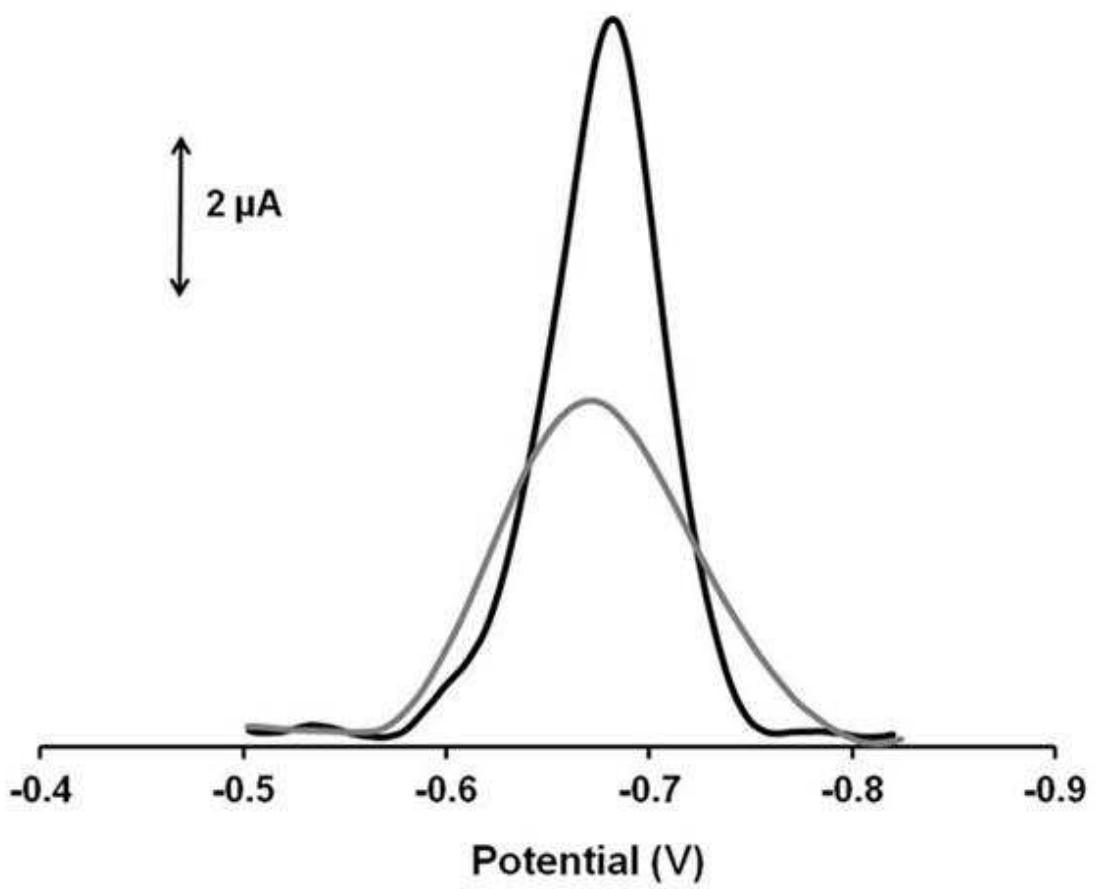

Figure S1. SW voltammograms of Cd(II) released from QDs after performing a binding assay of STV-modified CdSe/ZnS QDs with biotinylated BSA immobilized on a Biodyne B nylon membrane (black line) and on chromatographic paper (gray line). Preconentration time $240 \mathrm{~s}$, preconcentration potential $-1.40 \mathrm{~V}$.

\section{Calibration curves for streptavidin conjugated CdSe/ZnS and PbS quantum dots.}

The calibration plots for $\mathrm{CdSe} / \mathrm{ZnS}$ and $\mathrm{PbS}$ quantum dots (QDs) are presented in Figure S2 (panels A, B). The QDs calibrators are prepared after the appropriate dilution of stock QDs solutions ( $1 \mu \mathrm{mol} \mathrm{L}{ }^{-1} \mathrm{CdSe} / \mathrm{ZnS}$ and $0.43 \mu \mathrm{mol} \mathrm{L} \mathrm{L}^{-1} \mathrm{PbS}$ QDs) with $20 \mathrm{mmol} \mathrm{L}^{-1}$ phosphate buffered saline (PBS), $\mathrm{pH}$ 7.0. For this experiment, $10 \mu \mathrm{L}$ of the QD calibrator solution is applied to the assay zone of the membrane device for $15 \mathrm{~min}$. Next, $10 \mu \mathrm{L}$ of $0.01 \mathrm{~mol} \mathrm{~L}^{-1}$ $\mathrm{HCl}$ solution is added on the assay zone for $10 \mathrm{~min}$ in order to release cations from the QDs. The stripping analysis of released cations is carried out as described in the section $A S V$ 
measurements of the manuscript. The $R^{2}$ values of the curves are 0.998 for $\mathrm{CdSe} / \mathrm{ZnS}$ and 0.997 for PbS QDs.
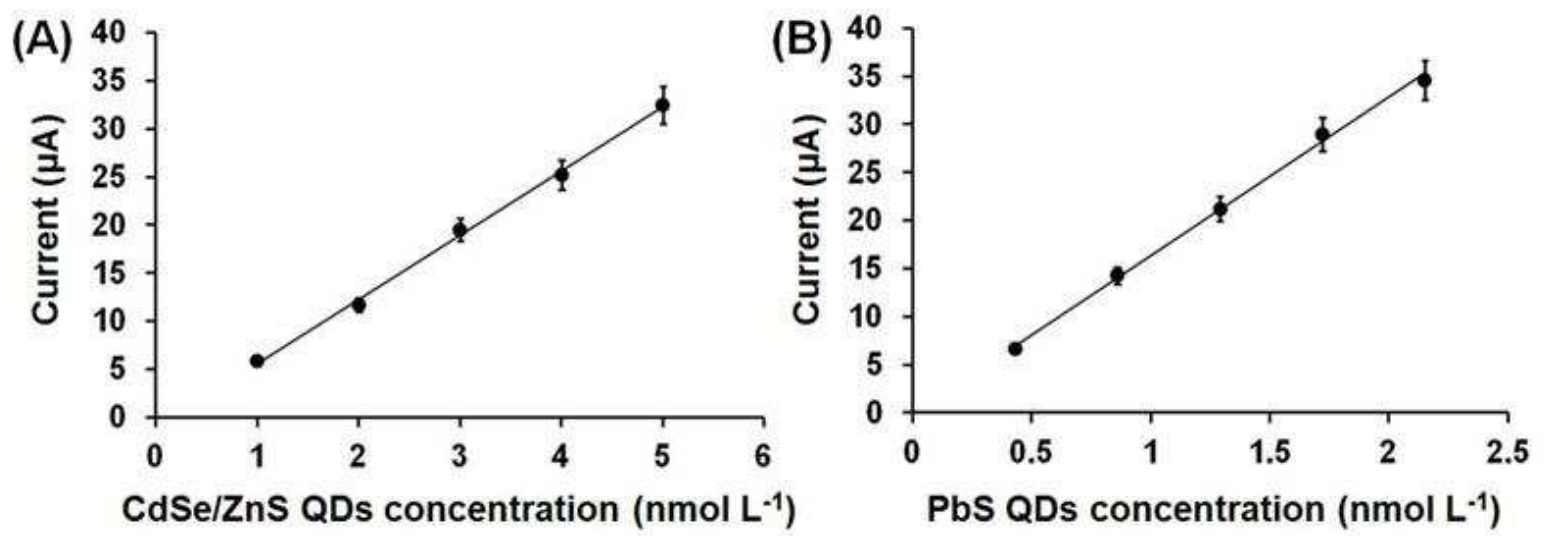

Figure S2. Calibration plots (stripping peak current $v s$ concentration) for (A) the CdSe/ZnS QDS and (B) the PbS QDs. Preconentration time $240 \mathrm{~s}$, preconcentration potential $-1.40 \mathrm{~V}$. Each point is the mean value of 4 replicates $\pm \mathrm{SD}$.

\section{IR analysis of nylon membrane.}

The IR spectrometer is a PerkinElmer Spectrum Version 10.4.3. The IR spectra of the Biodyne B nylon membrane without and after thermal treatment at $140{ }^{0} \mathrm{C}$ for $5 \mathrm{~h}$ and overnight are identical, showing that the membrane characteristics remain unaffected by the treatment at $140{ }^{\circ} \mathrm{C}$. 


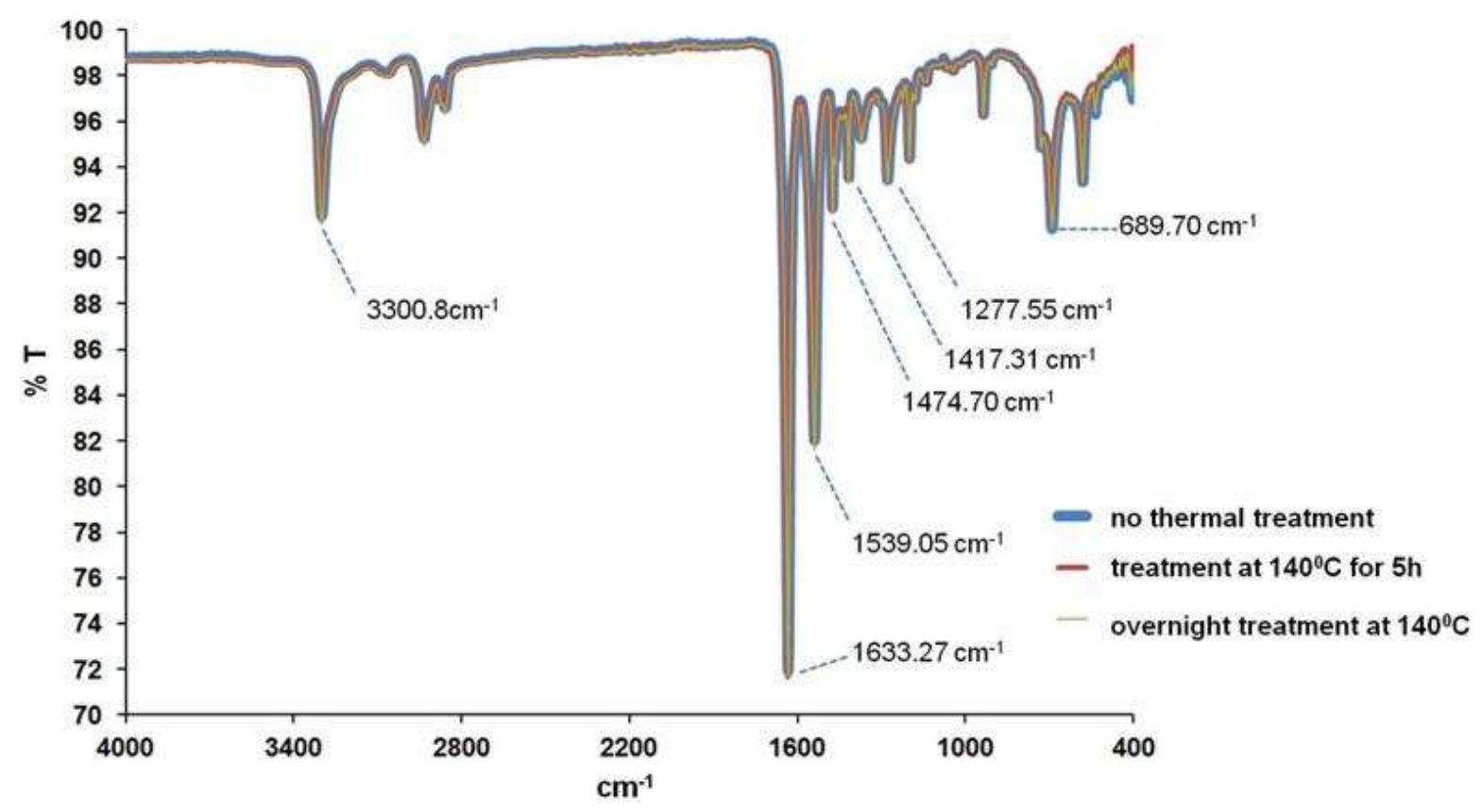

Figure S3. IR spectra of Biodyne B nylon membrane without (blue line) and after thermal treatment at $140{ }^{\circ} \mathrm{C}$ for $5 \mathrm{~h}$ (red line) and overnight (green line).

\section{SEM/EDX analysis.}

The surface morphology of the sensors is examined with a JSM-6510LV scanning electron microscope $(\mathrm{SEM})$ equipped with an INCA Penta FET $\times 3$ energy dispersive $\mathrm{X}$-ray (EDX) spectroscopy detector (Oxford Instruments). The SEM/EDX analysis of the working electrode surface (Figure S4) after treatment at $-1.40 \mathrm{~V}$ for $240 \mathrm{~s}$ shows that the Bi film consists of Bi nanoparticles that have a uniform distribution over the whole electrode surface. It has been shown before that citrate ions, released during the cathodic deposition step, support the formation of a better dispersed bismuth layer. ${ }^{1}$ It must be underlined that, the Bi film at electroplated electrodes, as well as at modified electrodes with other Bi precursors, consists of randomly distributed larger aggregates. ${ }^{1-3}$ The existence of $\mathrm{Bi}$ nanoparticles endows the device with valuable features, such as improved mass transport rate and high active surface area, resulting in the superior ASV detection sensitivity of $\mathrm{Pb}(\mathrm{II})$ and $\mathrm{Cd}(\mathrm{II})$. 


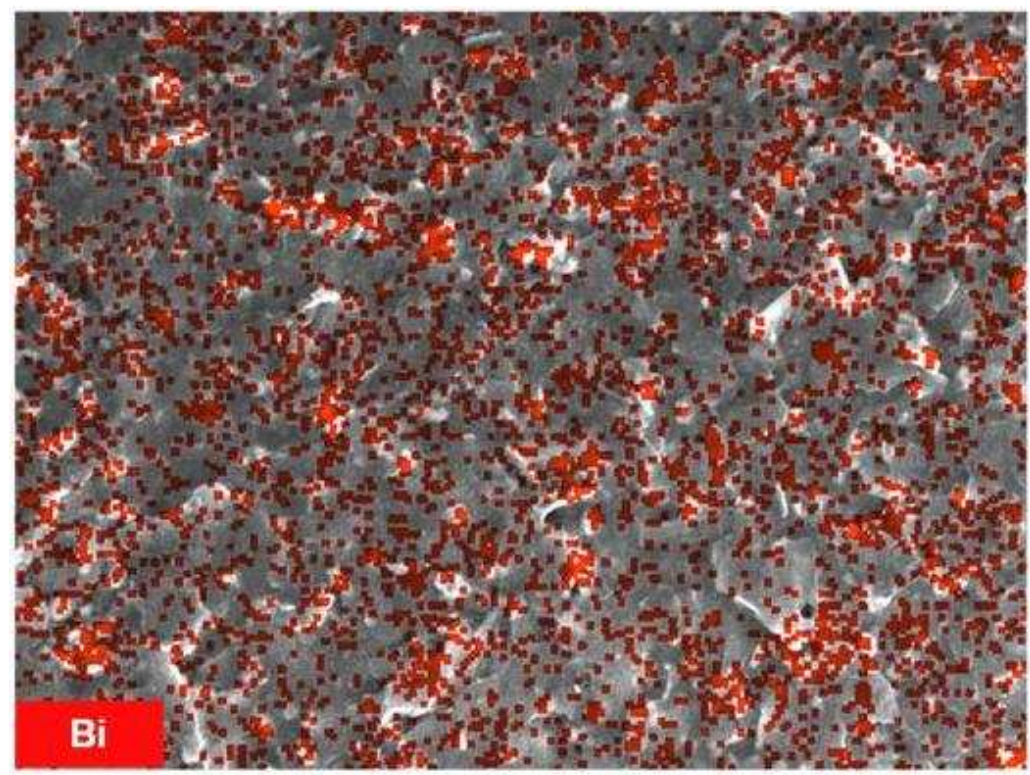

$50 \mu \mathrm{m}$

Figure S4. SEM image of the working electrode surface (modified with bismuth citrate) after polarization at $-1.40 \mathrm{~V}$ for $240 \mathrm{~s}$, with overlaid EDX mapping of Bi particles (red dots).

\section{Effect of preconcentration time and preconcentration potential.}

The effect of the preconcentration time and the preconcentration potential on the stripping response of $\mathrm{Cd}(\mathrm{II})$ and $\mathrm{Pb}(\mathrm{II})$ is tested using the respective zero calibrator solutions (Figure S5). It must be underlined that these parameters affect both the formation of bismuth nanostructured layer on the working electrode surface and the amount of the target metal deposited in the working electrode. In the case of the preconcentration time, the stripping responses increase quickly at shorter times and level-off at longer times. Regarding the variation in preconcentration potential, the stripping peaks of $\mathrm{Cd}(\mathrm{II})$ and $\mathrm{Pb}(\mathrm{II})$ are low at more positive potentials, as the potential is not sufficiently cathodic to initiate the accumulation of $\mathrm{Cd}$ and $\mathrm{Pb}$ and the reduction of the $\mathrm{Bi}$ precursor. On the other hand, at more 
negative values the stripping peak heights of $\mathrm{Cd}$ and $\mathrm{Pb}$ increase fast as the $\mathrm{Bi}$ film is more efficiently formed on the electrode surface and the amount of deposited $\mathrm{Cd}$ and $\mathrm{Pb}$ increases.
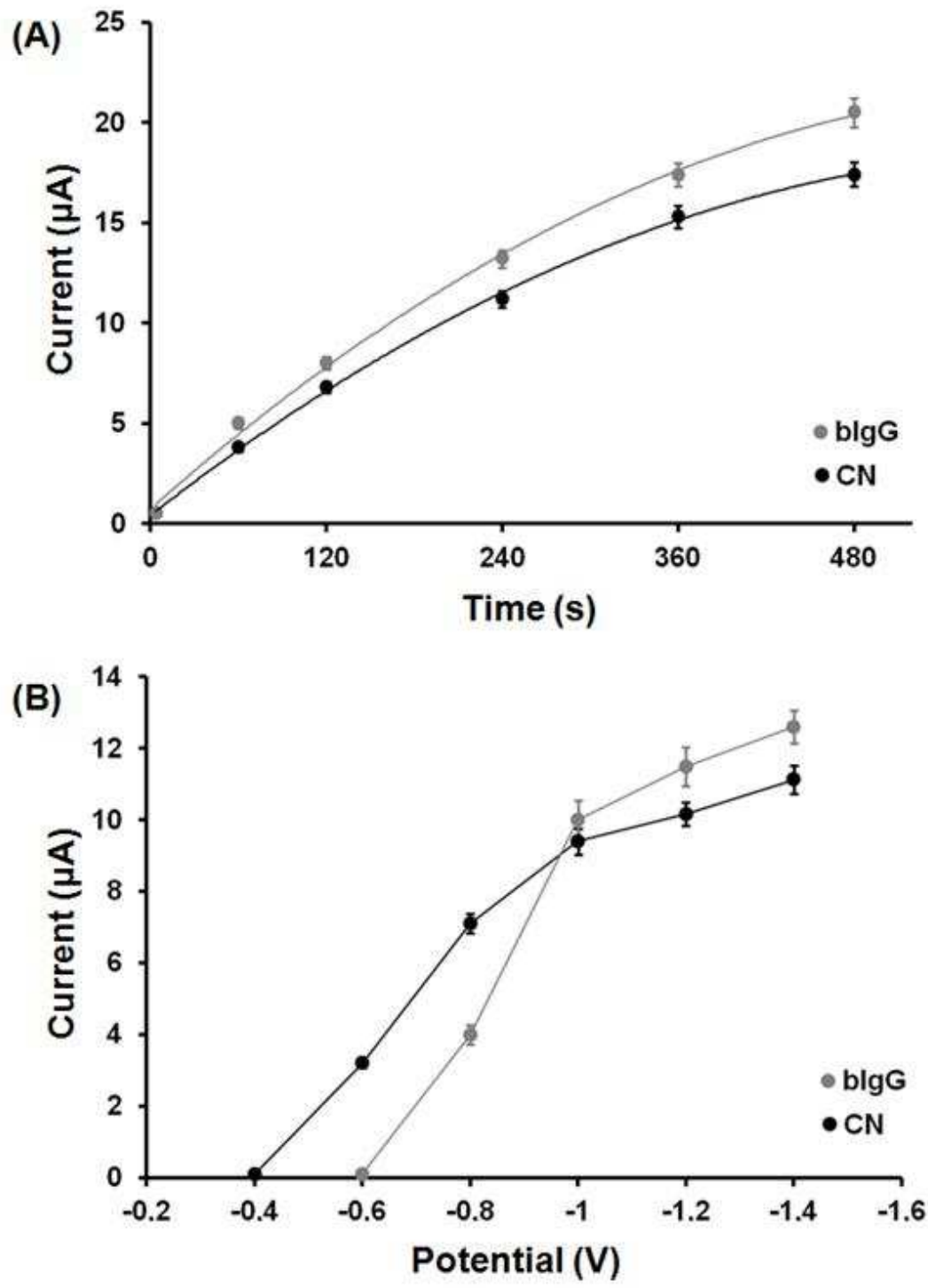

Figure S5. Effect of (A) the preconcentration time and (B) the preconcentration potential on stripping peak currents of $\mathrm{Pb}(\mathrm{II})$ and $\mathrm{Cd}(\mathrm{II})$ released after acidic dissolution of respective QDs used as labels for bovine casein and bovine IgG duplex immunoassays using zero calibrator solutions. Each point represents the mean value $\pm \operatorname{SD}(n=4)$. 


\section{ELISA for the detection of bovine casein $(\mathrm{CN})$.}

Microtitration wells are coated overnight with $100 \mu \mathrm{L}$ per well of a $10 \mu \mathrm{g} \mathrm{mL} \mathrm{m}^{-1}$ bovine $\mathrm{k}$-casein solution in $50 \mathrm{mmol} \mathrm{L}^{-1}$ carbonate buffer, $\mathrm{pH} 9.2$ (coating buffer). The wells are then washed twice with $300 \mu \mathrm{L}$ of $10 \mathrm{mmol} \mathrm{L}^{-1} \mathrm{PBS}$, pH 7.4 (washing buffer) and blocked with $300 \mu \mathrm{L}$ of $1 \%(\mathrm{w} / \mathrm{v})$ BSA solution in $0.1 \mathrm{~mol} \mathrm{~L}^{-1} \mathrm{NaHCO}_{3}, \mathrm{pH} 8.5$ (blocking solution), for 1 hour. After the completion of the blocking, the wells are washed twice with $300 \mu \mathrm{L}$ of washing buffer. For the assay, $50 \mu \mathrm{L}$ of bovine casein calibrators prepared in $10 \mathrm{mmol} \mathrm{L}^{-1}$ PBS, pH 7.4, containing $0.5 \%(\mathrm{w} / \mathrm{v}) \mathrm{BSA}$ (assay buffer) or milk samples diluted $8 \times 10^{4}$ times in the same buffer and $50 \mu \mathrm{L}$ of a solution containing the two anti-bovine $\mathrm{k}$-casein monoclonal antibodies at $40 \mathrm{ng} \mathrm{mL}^{-1}$ each in assay buffer are added to the wells and incubated for 1 hour under shaking. The wells are then washed four times with $300 \mu \mathrm{L}$ of washing solution and incubated with $100 \mu \mathrm{L}$ of a $5 \mu \mathrm{g} \mathrm{mL} \mathrm{m}^{-1}$ anti-mouse IgG antibody-HRP conjugate in $0.1 \mathrm{~mol} \mathrm{~L}^{-1}$ Tris- $\mathrm{HCl}$ buffer, $\mathrm{pH} 8.25$, containing $0.5 \%(\mathrm{w} / \mathrm{v}) \mathrm{BSA}$, and $0.9 \%(\mathrm{w} / \mathrm{v}) \mathrm{NaCl}$ (secondary antibody buffer), for $30 \mathrm{~min}$. Finally, the wells are washed four times with washing buffer and $100 \mu \mathrm{L}$ of HRP substrate solution $\left(0.03 \% \mathrm{v} / \mathrm{v} \mathrm{H}_{2} \mathrm{O}_{2}\right.$ and $1.9 \mu \mathrm{mol} \mathrm{L} \mathrm{L}^{-1}$ ABTS in $0.1 \mathrm{~mol} \mathrm{~L}^{-1}$ citrate-phosphate buffer, $\mathrm{pH} 4.5$ ) is added and incubated for $30 \mathrm{~min}$ under shaking. The optical density of the wells is measured at $405 \mathrm{~nm}$ with a Victor3 1420 Multilabel Counter (Perkin Elmer) and the calibration curve was constructed by plotting the signal of the different calibrators $\left(\mathrm{S}_{\mathrm{x}}\right)$ expressed as percentage of the zero calibrator signal $\left(\mathrm{S}_{0}\right)$ in logit/log scale. 


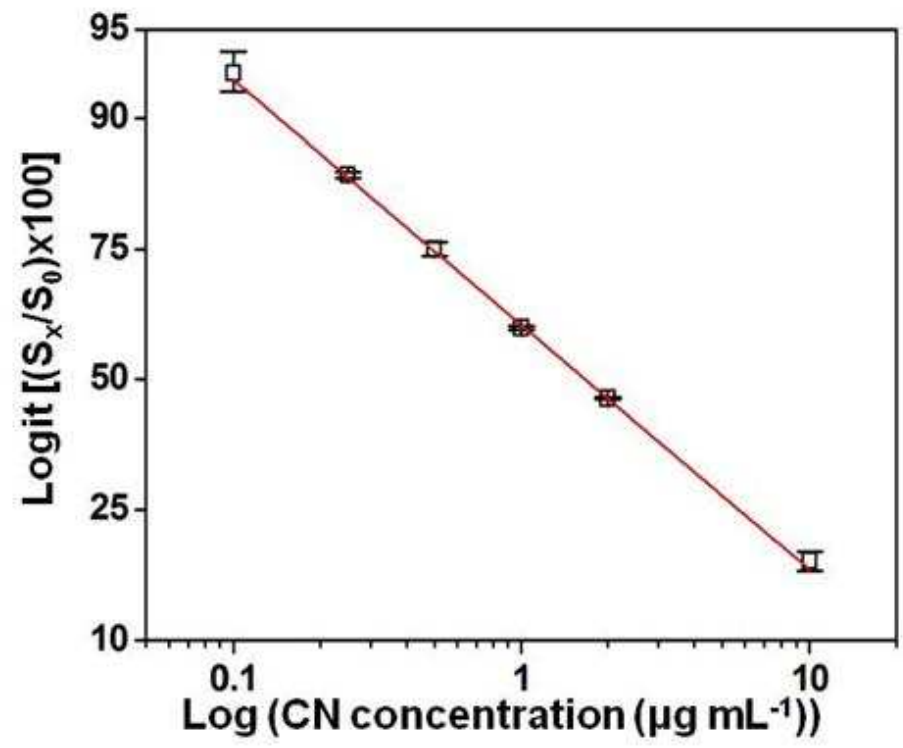

Figure S6. Typical ELISA bovine casein calibration curve. Each point is the mean value of three replicates $\pm S D$. The red line corresponds to linear regression $\left(\mathrm{R}^{2}=0.999\right)$.

\section{ELISA for the detection of bovine IgG (bIgG).}

Microtitration wells are coated overnight with $100 \mu \mathrm{L}$ per well of a $2 \mu \mathrm{g} \mathrm{mL}^{-1}$ bIgG solution in coating buffer. The wells are then washed twice with washing buffer and blocked with 300 $\mu \mathrm{L}$ of blocking solution for 1 hour. After the completion of the blocking, the wells are washed twice with $300 \mu \mathrm{L}$ of washing buffer. For the assay, $50 \mu \mathrm{L}$ of bIgG calibrators, prepared in assay buffer or samples diluted $2.5 \times 10^{3}$ times in the same buffer and $50 \mu \mathrm{L}$ of $150 \mathrm{ng} \mathrm{mL}-1$ rabbit anti-bovine IgG solution in assay buffer, are added to the wells and incubated for 1 hour under shaking. The wells are then washed four times with $300 \mu \mathrm{L}$ of washing solution and incubated with $100 \mu \mathrm{L}$ of a $5 \mu \mathrm{g} \mathrm{mL} \mathrm{m}^{-1}$ anti-rabbit $\operatorname{IgG}$ antibody-HRP conjugate in secondary antibody buffer for 30 min. Finally, the wells are washed four times with washing buffer and $100 \mu \mathrm{L}$ of HRP substrate solution $\left(0.03 \% \mathrm{v} / \mathrm{v} \mathrm{H}_{2} \mathrm{O}_{2}\right.$ and $1.9 \mu \mathrm{mol} \mathrm{L}{ }^{-1}$ ABTS in 0.1 mol L ${ }^{-1}$ citrate-phosphate buffer, $\mathrm{pH} 4.5$ ) is added and incubated for 30 min under shaking. 
The optical density of the wells was measured at $405 \mathrm{~nm}$ and the calibration curve was plotted in $\operatorname{logit} / \log$ scale.

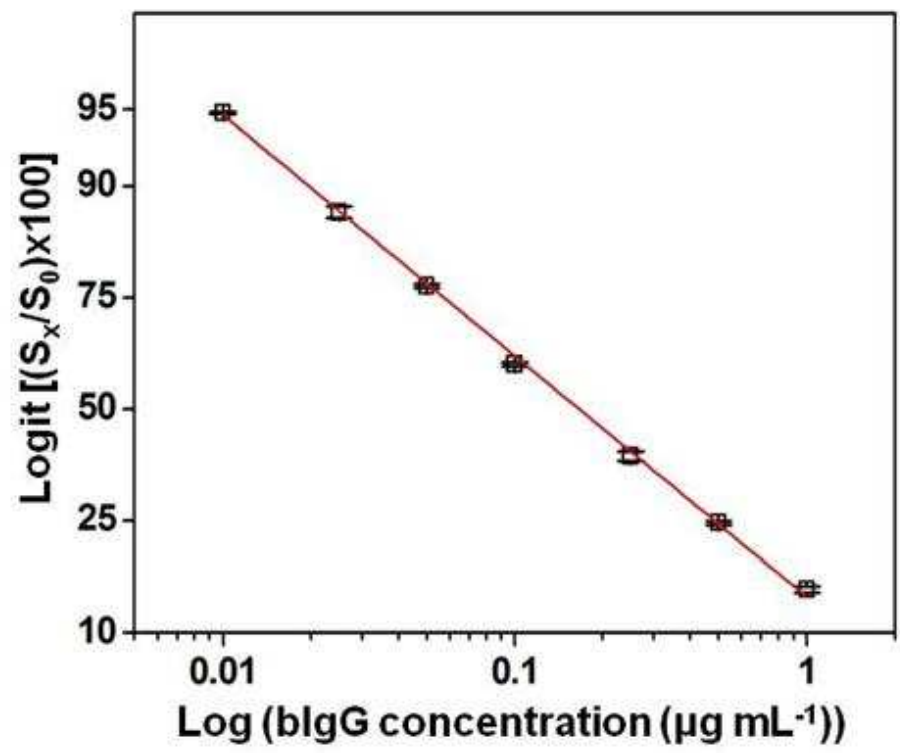

Figure S7. Typical ELISA bIgG calibration curve. Each point is the mean value of three replicates $\pm \mathrm{SD}$. The red line corresponds to linear regression $\left(\mathrm{R}^{2}=0.999\right)$. 
Recovery experiments for the simultaneous electrochemical determination of $\mathrm{CN}$ and

bIgG in spiked bovine milk samples.

Table S1. Recovery of CN and bIgG in Spiked Bovine Milk Samples and Comparison with ELISA

\begin{tabular}{|c|c|c|c|c|}
\hline $\begin{array}{l}\text { Sample } \\
\text { No }\end{array}$ & $\begin{array}{l}\text { Amount added } \\
\left(\mathrm{mg} \mathrm{mL}^{-1}\right)\end{array}$ & $\begin{array}{c}\text { Amount } \\
\text { determined } \\
\left(\mathrm{mg} \mathrm{mL}^{-1}\right)^{*}\end{array}$ & $\%$ recovery & $\begin{array}{c}\text { Amount } \\
\text { determined } \\
\text { by ELISA } \\
\left(\mathrm{mg} \mathrm{mL}^{-1}\right)^{*}\end{array}$ \\
\hline \multicolumn{5}{|c|}{$\overline{C N}$} \\
\hline \multirow{4}{*}{1} & $\overline{0}$ & $27.2( \pm 2.3)$ & - & $25.8( \pm 1.6)$ \\
\hline & 10 & $38.0( \pm 3.1)$ & 108 & - \\
\hline & 30 & $57.8( \pm 4.9)$ & 102 & - \\
\hline & 60 & $81.8( \pm 7.2)$ & 91 & - \\
\hline \multirow{4}{*}{2} & 0 & $25.1( \pm 1.9)$ & - & $26.6( \pm 1.4)$ \\
\hline & 10 & $35.3( \pm 2.9)$ & 103 & - \\
\hline & 30 & $53.4( \pm 4.7)$ & 94 & - \\
\hline & 60 & $83.2( \pm 7.7)$ & 97 & - \\
\hline \multicolumn{5}{|c|}{ bIgG } \\
\hline \multirow{4}{*}{1} & 0 & $0.27( \pm 0.02)$ & - & $0.26( \pm 0.01)$ \\
\hline & 0.25 & $0.53( \pm 0.04)$ & 104 & - \\
\hline & 0.50 & $0.73( \pm 0.05)$ & 92 & - \\
\hline & 1.0 & $1.31( \pm 0.12)$ & 104 & - \\
\hline \multirow{4}{*}{2} & 0 & $0.29( \pm 0.02)$ & - & $0.31( \pm 0.02)$ \\
\hline & 0.25 & $0.52( \pm 0.04)$ & 92 & - \\
\hline & 0.50 & $0.77( \pm 0.05)$ & 96 & - \\
\hline & 1.0 & $1.32( \pm 0.11)$ & 103 & - \\
\hline
\end{tabular}

*mean value $\pm \mathrm{SD}(\mathrm{n}=4)$ 


\section{Matrix effect of goat milk on the voltammetric response of the membrane device.}

In order to study the possible matrix effect of goat milk on the response of membrane devices, different goat milk dilutions are tested. In Figure $\mathrm{S} 8$, the stripping responses of $\mathrm{Cd}$ and $\mathrm{Pb}$ corresponding to zero calibrators of $\mathrm{CN}$ and bIgG as well as the respective non-specific binding signals are presented. It is shown that, when the goat milk dilution is equal to or higher than 50-fold, maximum stripping signals for the zero calibrators are obtained associated with low non-specific binding signals for both analytes. Using lower goat milk dilutions, the zero calibrator signal was decreased while the non-specific binding signal was increased. Thus, a 50-times dilution is selected. 


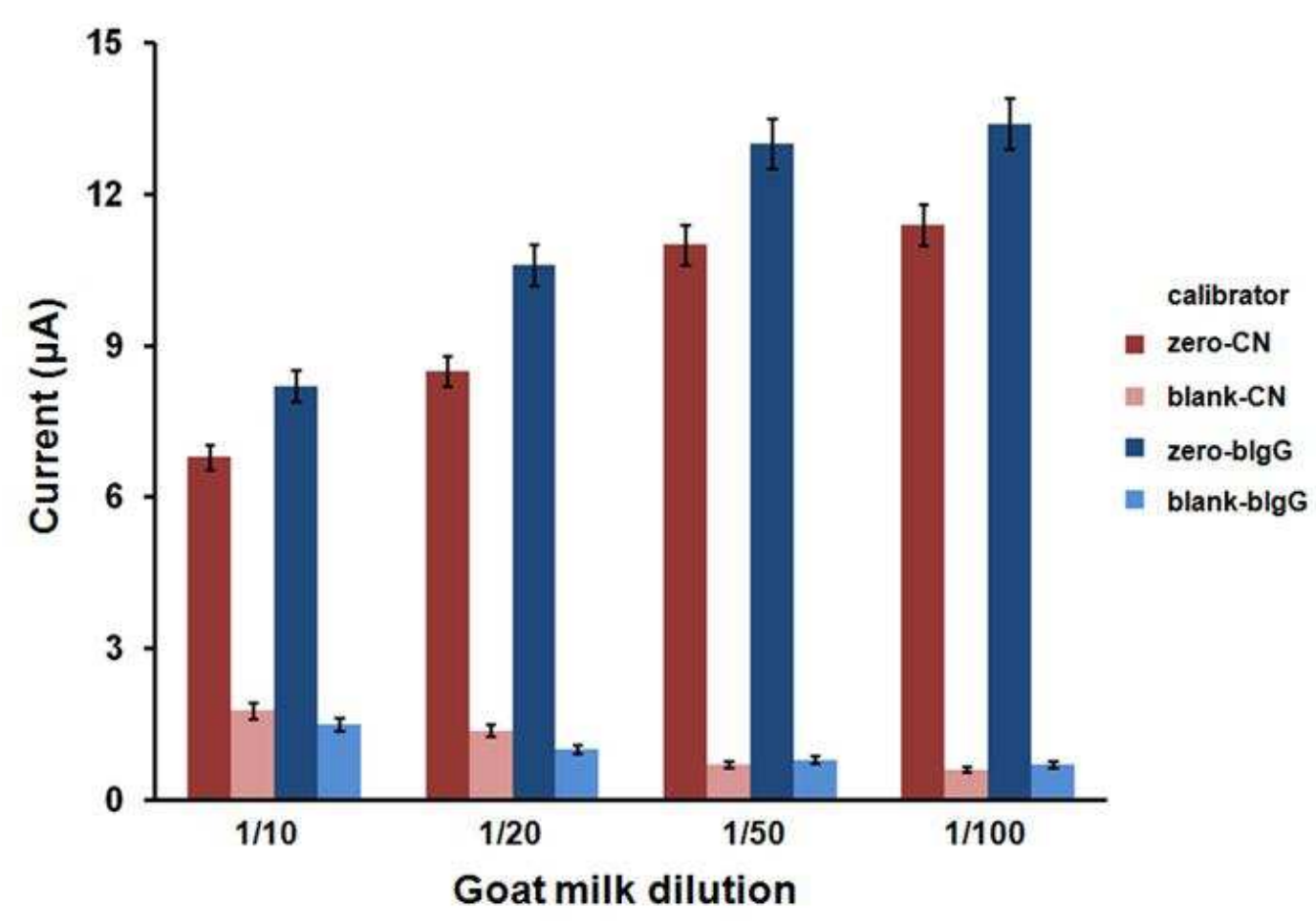

Figure S8. Effect of goat milk dilutions on the voltammetric response of membrane device assayed with different goat milk dilutions. Each bar is the mean stripping peaks currents for zero calibrators of bovine caseins and bovine $\operatorname{IgG}$, and the respective non-specific binding signals obtained from devices assayed with different goat milk dilutions. Error bars represent $\pm \mathrm{SD}(\mathrm{n}=4)$.

\section{References}

1] Lezi , N.; Economou, A.; Dimovasilis, P. A.; Trikalitis, P. N.; Prodromidis, M. I. Anal. Chim. Acta 2012, 728, 1-8.

2] Baldrianova, L.; Svancara, I. ; Vlcek, M.; Economou, A.; Sotiropoulos, S. Electrochim. Acta 2006, 52, 481-490.

3] Lezi , N.; Economou, A.; Barek, J.; Prodromidis, M. Electroanalysis 2014, 26, 766-775. 